\title{
Giant Humidity Effect on Hybrid Halide Perovskite Micro- Stripes: Reversibility and Sensing Mechanism
}

Md Azimul Haque ${ }^{\dagger}$, Ahad Syed ${ }^{\perp}$, Faheem Hassan Akhtar $^{\S}$, Rahul Shevate ${ }^{\S}$, Simrjit Singh ${ }^{\ddagger}$, Klaus- $^{-}$ Viktor Peinemann ${ }^{\S}$ Derya Baran ${ }^{\dagger}$, Tom $W^{\ddagger *}$

${ }^{\dagger}$ KAUST Solar Center (KSC), ${ }^{\perp}$ Core Labs, ${ }^{\S}$ Advanced Membranes and Porous Materials Center. Physical Science and Engineering Division, King Abdullah University of Science and Technology (KAUST), Thuwal 23955-6900, Saudi Arabia. ${ }^{\star}$ School of Materials Science and Engineering, University of New South Wales, Sydney, NSW 2052, Australia

Corresponding author: tom.wu@unsw.edu.au

KEYWORDS: hybrid perovskite, humidity, lithography, patterns, sensor

\section{ABSTRACT}

Despite the exceptional performance of hybrid perovskites in photovoltaics, their susceptibility to ambient factors, particularly humidity, gives rise to the well-recognized stability issue. In the present work, micro-stripes of $\mathrm{CH}_{3} \mathrm{NH}_{3} \mathrm{PbI}_{3}$ are fabricated on flexible substrates, and they exhibit much larger response to relative humidity $(R H)$ levels than continuous films and single crystals. The resistance of micro-stripes decreases by four orders of magnitude on changing the RH level from 10\% to 95\%. Fast response and recovery time of $100 \mathrm{~ms}$ and $500 \mathrm{~ms}$, respectively, are recorded. Because bulk diffusion and defect trapping are much slower process, our result indicates a surface-dictated mechanism related to hydrate formation and electron donation. In addition, water uptake behavior of perovskites is studied for the first time, which correlates well with the resistance decrease of the $\mathrm{CH}_{3} \mathrm{NH}_{3} \mathrm{PbI}_{3}$ micro-stripes. Furthermore, we report that the photoresponse decreases with increasing humidity, and at the $85 \% \mathrm{RH}$ level, the perovskite device is not photoresponsive anymore. Our work underscores patterned structures as a new platform to investigate the interaction of hybrid perovskites with ambient factors and reveals the importance of humidity effect on optoelectronic performance. 


\section{INTRODUCTION}

The exponential rise of hybrid perovskites as multifunctional materials has attracted significant attention from the research community. High-performance solar cells, photodetectors, lasers, LEDs, phototransistors have been extensively pursued..$^{1-6}$ In addition, interesting physical phenomena have been reported for hybrid perovskites such as ferroelectricity, ${ }^{7}$ photorestriction, ${ }^{8}$ resistive switching, ${ }^{9}$ and optical cooling. ${ }^{10}$ For practical applications and mass fabrication of hybrid halide perovskite-based electronic devices, it is imperative to develop industry scalable, facile micro-fabrication techniques. Standard lithographic techniques of micro-pattering cannot be applied to hybrid perovskites due to their incompatibility with the solvents used in the process. To overcome this issue, several alternative methods such as imprint lithography, spin-on pattering, templating, geometrical confinement, and wettability-assisted photolithography have been developed. ${ }^{11-15}$ Although these alternative methods were successful in producing micropatterns, the deviation from standard lithography technique restricts their applications.

Another obstacle in the progress of hybrid perovskites is their instability under humid conditions. The interaction of moisture with perovskite is a double-edge sword, which on one hand can lead to acute degradation of perovskites. ${ }^{16}$ On the other hand, a meticulous amount of moisture has a positive effect on the photovoltaic performance. ${ }^{17}$ Thus, it is crucial to understand the humidity effect in order to develop robust perovskite devices. Particularly, how humidity affects the physical and optoelectronic properties of scaled-down hybrid perovskite micropatterns remains an open question.

In the present work, we fabricated hybrid perovskite micro-stripes on flexible substrates using a facile two-step patterning approach based on optical lithography and dip coating. The effect of moisture on the transport properties of these perovskite micro-patterns was studied in a wide 
humidity range. As a chemiresistive sensor, the resistance of perovskite micro-stripes decreases by four orders of magnitude with unprecedented fast response and recovery time. Furthermore, the photoresponse of the micro-patterned perovskite decreases with increasing humidity and finally becomes unresponsive to light at $85 \% \mathrm{RH}$. These results on micropatterns usher in a new perspective on the humidity effect on the physical properties of hybrid perovskites.

\section{EXPERIMENTAL SECTION}

Materials: $\mathrm{PbI}_{2}(99.9985 \%)$ was purchased from Alfa-Aesar and $\mathrm{CH}_{3} \mathrm{NH}_{3} \mathrm{I}$ from Dyesol. All other materials were purchased from Sigma-Aldrich and were used as received unless otherwise stated.

Perovskite patterns, film, and Single crystal growth: For perovskite pattering, $1 \mathrm{M} \mathrm{PbI}_{2}$ was dissolved in DMSO and spin coated on ITO coated PET substrates at $5000 \mathrm{rpm}$. After spin coating, $\mathrm{PbI}_{2}$ coated substrates were annealed at $80{ }^{\circ} \mathrm{C}$ for 10 minutes. $\mathrm{PbI}_{2}$ coated substrates were spin coated with ECI 3027 photoresist. The spin coating process had 3 steps with parameters; step 1 (700 rpm, $1000 \mathrm{rpm}$ ramp, 3s), step 2 (1200 rpm, $1500 \mathrm{rpm}$ ramp, 3s), step 3 (1750 rpm, $3000 \mathrm{rpm}$ ramp, 30s) resulting in a thickness of $\sim 4 \mu \mathrm{m}$. Prebaking of the coated resist was for $60 \mathrm{~s}$ at $100{ }^{\circ} \mathrm{C}$. The resist coated samples were exposed to $200 \mathrm{~mJ} / \mathrm{cm}^{2} \mathrm{UV}$ dose using EVG6200 contact aligner. The exposed samples were then developed in AZ726 developer for 60s after which they were rinsed in DI water for $60 \mathrm{~s}$ to stop the development process. Finally, the samples were blown dry using nitrogen. For removing the photoresist, the developed samples were washed with acetone and dried with $\mathrm{N}_{2}$. To convert patterned $\mathrm{PbI}_{2}$ to perovskite, the substrates were dipped in isopropanol containing $10 \mathrm{mg} / \mathrm{ml} \mathrm{CH}_{3} \mathrm{NH}_{3} \mathrm{I}$ inside a glove box. Then the films were washed with isopropanol to remove excess $\mathrm{CH}_{3} \mathrm{NH}_{3} \mathrm{I}$. The converted perovskite was heated on a hot plate for 10 minutes at $100{ }^{\circ} \mathrm{C} . \mathrm{CH}_{3} \mathrm{NH}_{3} \mathrm{PbI}_{3}$ single crystals were synthesized 
as per a previous report. ${ }^{18}$ Briefly, $0.9 \mathrm{M}$ solution of $\mathrm{PbI}_{2}$ and $\mathrm{CH}_{3} \mathrm{NH}_{3} \mathrm{I}$ in $\gamma$-Butyrolactone in a vial was prepared and mixed at $80{ }^{\circ} \mathrm{C}$. Once a clear solution was obtained, the vial was transferred to an oil bath in air. The temperature of the oil bath was increased slowly till $180{ }^{\circ} \mathrm{C}$ around which the crystals start to appear. Crystals with 3-5 $\mathrm{mm}$ in size were then removed from the hot solution and dried under dry $\mathrm{N}_{2} \cdot \mathrm{CH}_{3} \mathrm{NH}_{3} \mathrm{PbBr}_{3}$ single crystals were grown according to a previous report. $^{19}$

Material characterization: Scanning electron microscopy (SEM) images were obtained using FEI Nova Nano. XRD Patterns were obtained from Bruker D8 Advance Diffractometer. FTIR spectra were recorded using Thermo Scientific ATR-FTIR spectrometer.

Sensor measurement: For preparing chemiresistive sensors, perovskite patterns were fabricated on ITO-coated PET substrates. Channel length and width of the sensors are 500 and $5000 \mu \mathrm{m}$, respectively. In case of single crystal devices, gold electrodes were deposited using a shadow mask. The schematic architectures for the micro-stripes, film, and single crystal devices are shown in Figure $\mathbf{S} 1$. To benchmark the performance of perovskite micro-stripes, a commercial humidity sensor (KTJ) was used. A custom-made set up was used for humidity testing. Controlled level of humidity was introduced into the testing chamber by a humidity generator (InstruQuest, HumiSys) using $\mathrm{N}_{2}$ as the carrier gas. For compact perovskite film devices, similar procedure was followed. All measurements were done in dark unless mentioned otherwise. For measurements under light, a small LED lamp with $10 \mathrm{~mW} / \mathrm{cm}^{2}$ was used to illuminate the sample through a window in the measurement chamber. The sensor was connected to a semiconductor analyzer (Keithley 4200) for data acquisition. Then the sensor response at desired humidity levels was measured by recording current-voltage characteristics of the sensor. For the 
desorption process, humidity was decreased from $95 \%$ to $10 \%$ RH in steps by introducing dry $\mathrm{N}_{2}$ in a controlled manner.

Water sorption measurement: Water vapor sorption experiments for the perovskite powder were conducted at $25{ }^{\circ} \mathrm{C}$ using a gravimetric sorption balance method on VTI-SA sorption analyzer from TA Instruments, USA. Once the mass uptake reached equilibrium for a given activity, the system proceeded to the next programmed step for activity. Equilibrium was considered when the mass uptake reached below a threshold limit $(0.001 \%$ mass change in 120 min) over a specified time interval. The sample was dried inside the sorption analyzer chamber at $60{ }^{\circ} \mathrm{C}$ for $2 \mathrm{~h}$ prior to the measurements to achieve a constant weight. Perovskite powder was obtained by grinding the single crystals using mortar and pestle.

\section{RESULTS AND DISCUSSION}

The method of micro-patterning hybrid perovskites is illustrated in Figure 1a. In the first step, lead iodide $\left(\mathrm{PbI}_{2}\right)$ in DMSO was spin coated on ITO coated PET substrates. Compact $\mathrm{PbI}_{2}$ films were produced, as observed in the scanning electron microscope (SEM) image (Figure 1b). Afterwards, a photoresist was coated on the $\mathrm{PbI}_{2}$ layer, and micro-stripes were produced using the standard photolithography process. In the second step, substrates with the $\mathrm{PbI}_{2}$ patterns were dipped into the solution of methylammonium iodide, (MAI) in isopropanol (IPA), which instantaneously turned the color of patterns from yellow to dark brown indicating the formation of methylammonium lead iodide.

Figure 1c-d shows the SEM images of the methylammonium lead iodide $\left(\mathrm{CH}_{3} \mathrm{NH}_{3} \mathrm{PbI}_{3}\right)$ micro-stripes with widths of 5 and $50 \mu \mathrm{m}$, respectively. The magnified SEM image in Figure 1e shows the polycrystalline surface of the stripes. The present technique allows scalability up to centimeter scales (Figure S2), which may be potentially applied to the fabrication of multiplexed 
optoelectronic devices. In addition, such patterned perovskites can serve as a viable approach to achieving semitransparent devices such as window-mounted photovoltaic systems. ${ }^{20}$ There was no change in the quality of the $\mathrm{PbI}_{2}$ after the development process (Figure 1f) as evidenced from the X-ray diffraction (XRD) data. The XRD pattern for the converted $\mathrm{CH}_{3} \mathrm{NH}_{3} \mathrm{PbI}_{3}$ stripes is shown in Figure 1g.

a

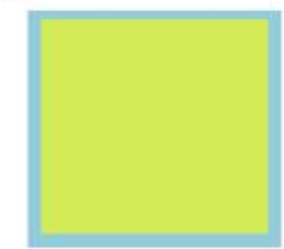

Glass/PET

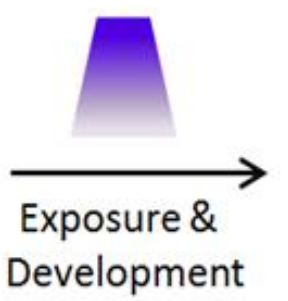

$\mathrm{Pbl}_{2}$
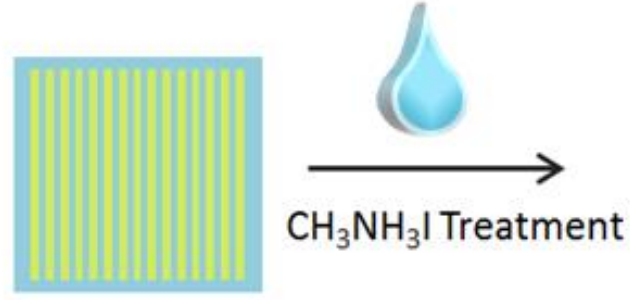

$\mathrm{CH}_{3} \mathrm{NH}_{3}$ I Treatment

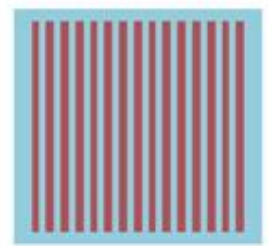

b
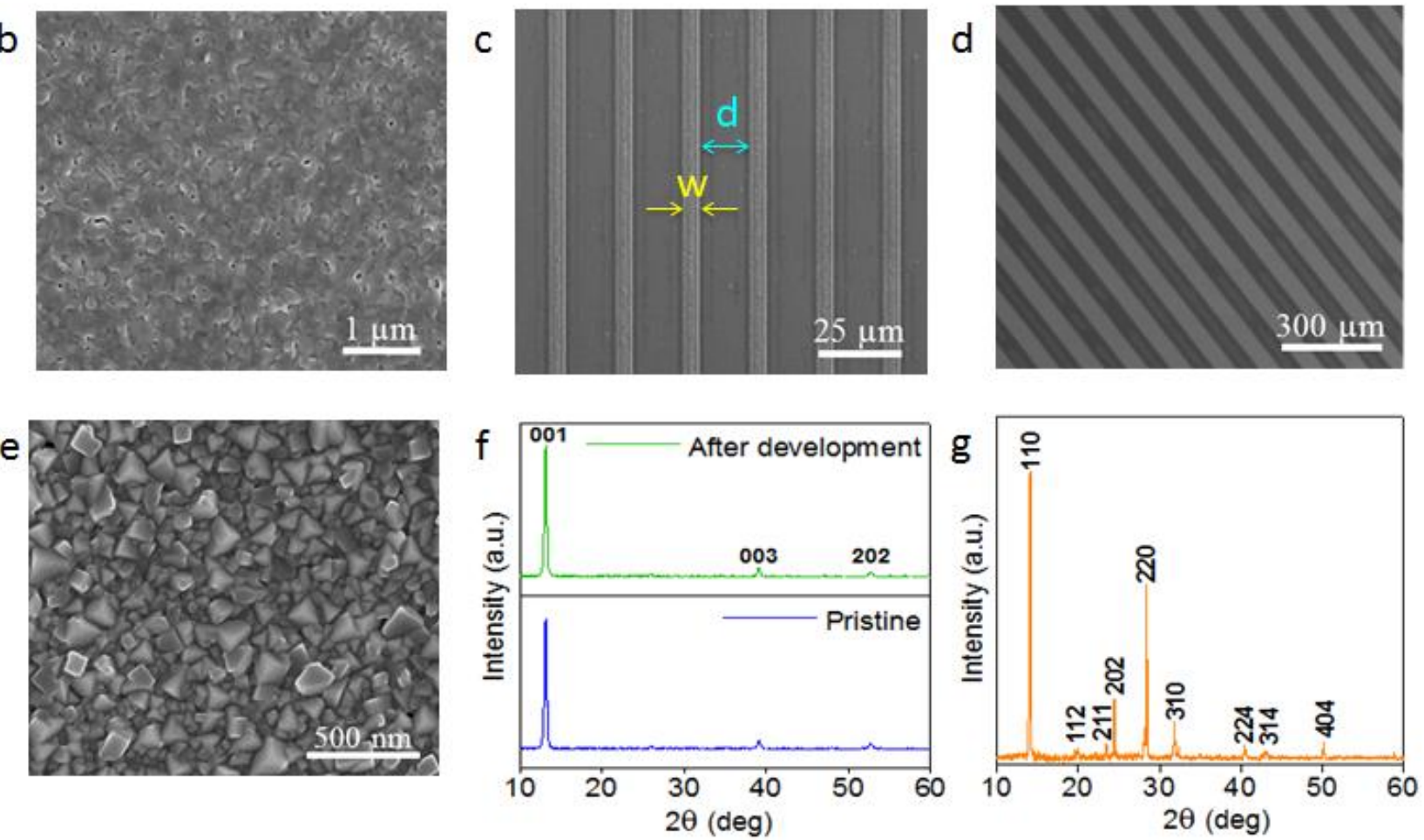

Figure 1. (a) Schematic process overview of the photolithography assisted pattering of $\mathrm{CH}_{3} \mathrm{NH}_{3} \mathrm{PbI}_{3}$.SEM images of (b) Spin-coated $\mathrm{PbI}_{2}$ and $\mathrm{CH}_{3} \mathrm{NH}_{3} \mathrm{PbI}_{3}$ micro-stripes with widths of (c) $5 \mu \mathrm{m}$ and (d) $50 \mu \mathrm{m}$. (e) Surface of the $\mathrm{CH}_{3} \mathrm{NH}_{3} \mathrm{PbI}_{3}$ micro-stripes. (f) $\mathrm{XRD}$ patterns of pristine and developed $\mathrm{PbI}_{2}$ films, exhibiting no change. (g) XRD pattern of the converted $\mathrm{CH}_{3} \mathrm{NH}_{3} \mathrm{PbI}_{3}$ micro-stripes. 
To investigate the moisture effect on the perovskite micro-stripes, flexible two-terminal planar chemiresistive sensors were fabricated. As schematically shown in the inset of Figure 2a, stripes with a width of $5 \mu \mathrm{m}$ were fabricated on ITO-coated PET substrates. A custom designed set up was used to carry out the sensor testing under different RH levels (Figure S3). Nitrogen $\left(\mathrm{N}_{2}\right)$ was employed as the carrier gas and for purging the chamber. The sensor response (resistance change) was monitored in real time by recording the current-voltage $(I-V)$ characteristics. As shown in Figure 2a-b, the resistance of the $\mathrm{CH}_{3} \mathrm{NH}_{3} \mathrm{PbI}_{3}$ stripe sensor decreases with increasing humidity levels $(10 \%-95 \%)$. There is an abrupt increase of current when the humidity increases from $75 \%$ to $85 \%$ RH (Figure $2 \mathrm{~b}$ ), which indicates enhanced moisture adsorption in this humidity range, as discussed in the later section. The resistance at 95\% RH is four orders of magnitude lower than that at 10\% RH (Figure S4), which reveals a giant moisture-induced effect on the transport property of perovskite micro-stripes. The sensor was also exposed to multiple cycles of humidity between $10 \%$ and $75 \%$ and showed excellent stability and reproducibility of the device (Figure 2c).

The sensor response to humidity exposure is determined from the negative change in conductance $\left[-\Delta \mathrm{G} / \mathrm{G}_{0}(\%)=\left(\mathrm{I}_{0}-\mathrm{I}\right) / \mathrm{I}_{0} \times 100 \%\right]$, where $\mathrm{I}_{0}$ is initial current which in the present case is taken as the value at $10 \% \mathrm{RH}$ and I is the current measured at different RH levels. ${ }^{21}$ The relative change in the conductance taking the current values at a potential bias of $2 \mathrm{~V}$ is plotted in Figure 2d. The sensitivity increases with increasing humidity levels (30\%-95\%) reaching a value $>10^{6}$ for $95 \%$ RH. Furthermore, a very fast hydration and dehydration process is witnessed in the adsorption and desorption measurements which showed almost no change in the sensing response during both the processes. Interestingly, the performance of the present sensor towards humidity is on par with some porous polymers. ${ }^{22}$ Leveraging the flexible nature of the sensor, it 
was subjected to different bending radius and bending cycles which produced a negligible change in the performance (Figure S5).
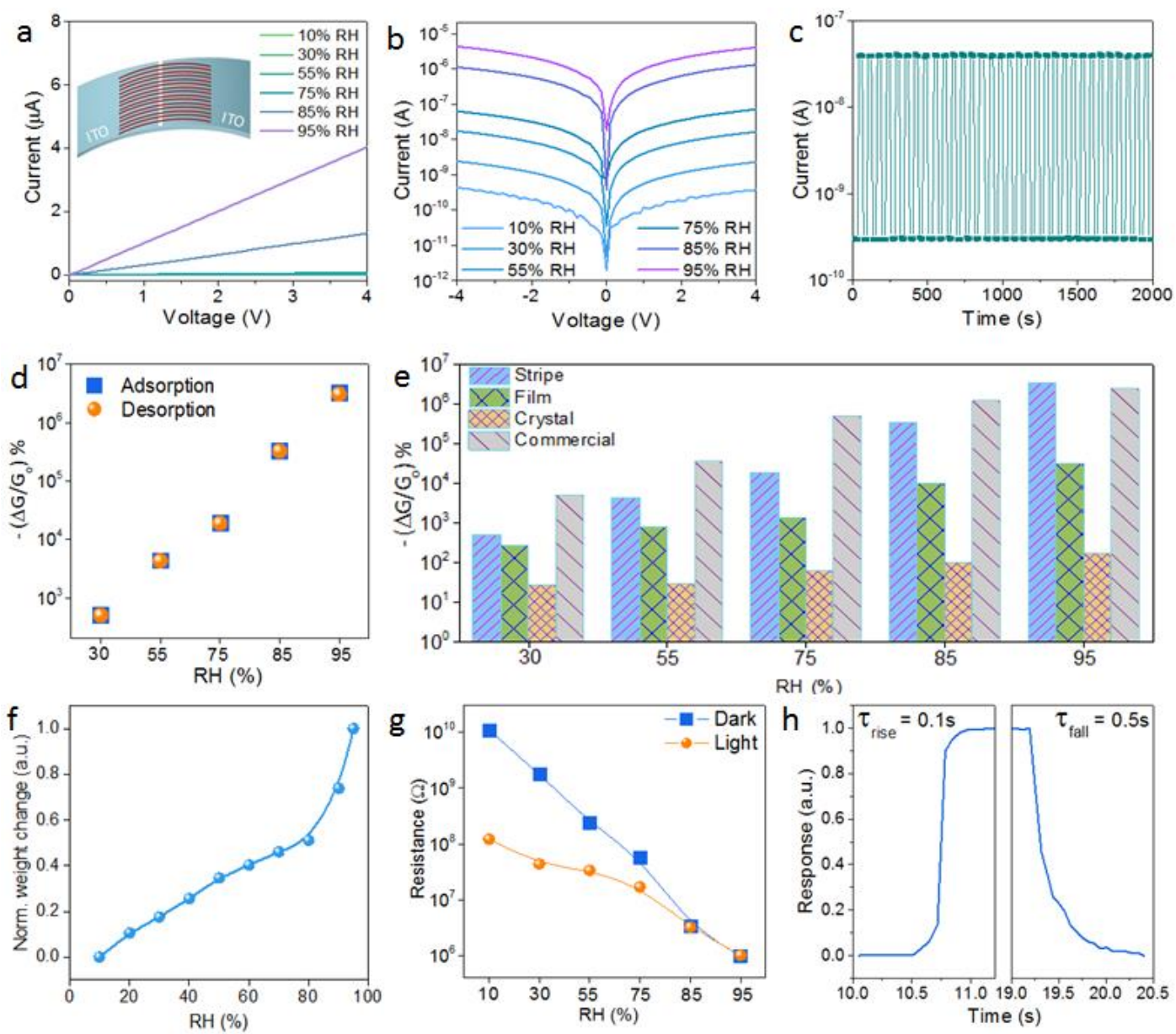

Figure 2. (a) $I-V$ characteristics of the perovskite micro-stripe as a function of RH in linear scale. (b) Logarithmic representation of the $I-V$ data. (c) Multiple cycles of humidity switching between $10 \%$ and $75 \%$. (d) Response as a function of RH levels and reversible adsorptiondesorption behavior. (e) Comparison of the sensor response as a function of RH levels for perovskite micro-stripe, film, single crystal and commercial humidity sensor. (f) Water sorption behavior of hybrid perovskites at $25^{\circ} \mathrm{C}$. (g) Change in the device resistance as a function of $\mathrm{RH}$ levels in dark and light. (h) Transient response at 95\% RH for perovskite micro-stripes.

The performance of the perovskite micro-stripe based humidity sensor is further compared with sensors based on compact perovskite films, single crystals, and commercial humidity sensor. For compact perovskite film, 2.5 order of magnitude change in the resistance was observed, whereas in the case of single crystals less than five-time change in the resistance was 
observed, implying the stronger role played by the surface area and grain boundaries in these devices (Figure S6). The lower performance of the single crystals can be due to the absence of grain boundaries as primary perturbation occurs at the grain boundaries in the presence of humidity and the much smaller total surface area. ${ }^{23}, 24$ The sensor response at different humidity levels for perovskite stripes, films, single crystal, and commercial humidity sensor is shown in Figure 2e. The order of response to humidity was stripes > film > single crystal. It is interesting to note that the perovskite stripe based sensor performs on par with the commercial one at higher humidity levels.

To gain further insights into the resistance change mechanism with increasing humidity, we performed water sorption measurements. To the best of knowledge, this is the first time that water sorption measurements on hybrid perovskites are accomplished, providing insights into their water uptake behavior. The water sorption measurements were performed on perovskite powder (more details in the experimental section) as the weight change of perovskite films and micro-stripes is too small to achieve reliable measurement. The water uptake clearly (Figure 2f) correlates with systematic decrease of resistance under different humidity levels. There is a steep increase in the water uptake after $80 \% \mathrm{RH}$, which is consistent with the jump in the device current at the same RH level (Figure 2a).

It has been reported that light can aid the degradation process of perovskite under humid conditions. ${ }^{23}$ To understand the effect of illumination on perovskite-humidity interaction, we monitored the sensor resistance under illumination $\left(10 \mathrm{~mW} / \mathrm{cm}^{2}\right)$ at different humidity levels. The photoconductivity of perovskite micro-stripes decreased significantly with increasing humidity levels (Figure $2 \mathrm{~h}$ ) and at RH levels $\geq 85 \%$, the photo activity was completely lost (Figure S7). The photo inactivity at very high humidity levels can be attributed to accelerated 
recombination of photogenerated carriers. ${ }^{25}$ Within the present experimental conditions, to obtain best optoelectronic performance, perovskite devices should be encapsulated or operated at humidity levels lower than $33 \% \mathrm{RH}$.

Table 1. Summary of humidity sensors based on various functional materials.

\begin{tabular}{|c|c|c|c|c|c|}
\hline S.N. & Material & $\begin{array}{c}\text { Response } \\
\text { Time (s) }\end{array}$ & $\begin{array}{c}\text { Recovery Time } \\
\text { (s) }\end{array}$ & $\underset{(\%)}{\mathrm{RH} \text { range }}$ & Ref. \\
\hline 1. & Porous $\mathrm{TiO}_{2}$ & 5 & 8 & $11-95$ & 26 \\
\hline 2. & $\begin{array}{c}\mathrm{LiCl} \text { doped } \mathrm{TiO}_{2} \\
\text { nanofiber }\end{array}$ & $<3$ & $<7$ & $11-95$ & 27 \\
\hline 3. & $\mathrm{ZnO}$ nanocrystals & 50 & 6 & $5-85$ & 28 \\
\hline 4. & $\begin{array}{l}\mathrm{TiO}_{2} \text { incorporated } \\
\text { sulfonated } \\
\text { polystyrene }\end{array}$ & $<2$ & 20 & $33-95$ & 29 \\
\hline 5. & $\begin{array}{c}\text { Nanoporous } \\
\text { polymeric photonic } \\
\text { crystals }\end{array}$ & 1.5 & $20-30$ & $20-100$ & 30 \\
\hline 6. & CdS nanoparticles & 60 & 30 & $17-85$ & 31 \\
\hline 7. & $\mathrm{CuO} / \mathrm{ZnO}$ nanocorals & 6 & 7 & $32-96$ & 32 \\
\hline 8. & $\begin{array}{c}\text { Au nanorod } \\
\text { embedded polymer } \\
\text { nanofibers }\end{array}$ & - & 0.11 & $30-71$ & 33 \\
\hline 9. & $\begin{array}{l}\text { Sulfonated block } \\
\text { copolymers }\end{array}$ & 5 & 5 & $20-95$ & 34 \\
\hline 10. & $\mathrm{Al}_{2} \mathrm{O}_{3}$ nanotubes & 10 & 20 & $11-95$ & 35 \\
\hline 11. & $\begin{array}{l}\text { Polyaniline } \\
\text { nanofibers }\end{array}$ & 8 & 6 & $11-98$ & 36 \\
\hline 12. & $\begin{array}{l}\text { Sulfonated } \\
\text { polystyrene }\end{array}$ & $<30$ & 300 & $11-90$ & 37 \\
\hline 13. & $\mathrm{Na}-\mathrm{ZnO}$ nanofiber & 3 & 6 & $11-95$ & 38 \\
\hline 14. & $\begin{array}{c}\text { Cross-linked } \\
\text { polyelectrolyte } \\
\text { derivatives } \\
\end{array}$ & 175 & 125 & $33-94$ & 39 \\
\hline 15. & $\begin{array}{l}\text { Sulfonated } \\
\text { polyimides }\end{array}$ & 70 & 230 & $30-90$ & 40 \\
\hline 16. & $\begin{array}{l}\text { Isoporous SWCNT- } \\
\text { PS- } b \text {-P4VP films }\end{array}$ & 0.3 & $\sim 4$ & $10-95$ & 22 \\
\hline 17. & $\mathrm{SnO}_{2}$ nanowire & 120 & 20 & $30-85$ & 41 \\
\hline 18. & $\mathrm{SrTiO}_{3}$ nanospheres & 2 & 2 & $11-95$ & 42 \\
\hline 19. & $\mathrm{PANI} / \mathrm{CaTiO}_{3}$ & 500 & 453 & $15-95$ & 43 \\
\hline 20. & $\begin{array}{c}\mathrm{CH}_{3} \mathrm{NH}_{3} \mathrm{PbI}_{3} \\
\text { stripes }\end{array}$ & 0.1 & 0.5 & $10-95$ & $\begin{array}{c}\text { Present } \\
\text { work }\end{array}$ \\
\hline
\end{tabular}


A response time (for the signal to increase from $10 \%$ to $90 \%$ ) and recovery time (for the signal to decrease from $90 \%$ to $10 \%$ ) of $100 \mathrm{~ms}$ and $500 \mathrm{~ms}$, respectively, were recorded for the perovskite sensor (Figure $2 \mathrm{~g}$ ). The physically absorbed water molecules are loosely bound to the surface and can be quickly removed when the humidity level decreases or dry $\mathrm{N}_{2}$ is passed over the sample, as evident from the quick recovery time. ${ }^{44}$ The response speed of the present humidity sensor is one of the best among the reports in literature to date (Table 1). In addition, the overall performance of the present perovskite micro-stripe sensor is superior to previously reported hybrid perovskite-based humidity sensors (Table 2). The high sensitivity of perovskite micro-stripes to humidity and the fast response speed underscore their potential for sensor applications.

In this study, we observed reversible operation of the devices when exposed to different humidity levels as long as the exposure duration is short enough. Devices exhibited stable performance for multiple cycles of humidity switching (Figure 3). It should be noted that $\mathrm{N}_{2}$ was used as the carrier gas as well as for purging in this study. It was recently reported that due to high diffusivity, $\mathrm{N}_{2}$ molecules interact with the molecular structure of the hybrid perovskite and obstructs the desorption of volatile species in the presence of moisture. ${ }^{45}$ The role of $\mathrm{N}_{2}$ in improving the stability of perovskites under humid conditions will be discussed later.

Table 2. Summary of humidity sensors based on hybrid perovskite.

\begin{tabular}{|c|c|c|c|c|c|c|}
\hline Material & Method & $\begin{array}{c}\text { Order of } \\
\text { Resistance } \\
\text { change }\end{array}$ & $\begin{array}{l}\text { Response } \\
\text { Time (s) }\end{array}$ & $\begin{array}{l}\text { Recovery } \\
\text { Time (s) }\end{array}$ & $\begin{array}{c}\text { RH } \\
\text { range } \\
(\%) \\
\end{array}$ & Ref. \\
\hline $\begin{array}{c}\mathrm{CH}_{3} \mathrm{NH}_{3} \mathrm{PbI}_{3-\mathrm{x}} \mathrm{Cl}_{\mathrm{x}} \\
\text { Film } \\
\end{array}$ & $\mathrm{I}-\mathrm{V}$ & 0.4 & - & 74 & $32-97$ & 46 \\
\hline $\begin{array}{c}\mathrm{CH}_{3} \mathrm{NH}_{3} \mathrm{PbI}_{3-\mathrm{x}} \mathrm{Cl}_{\mathrm{x}} \\
\text { Nanosheet array }\end{array}$ & $\mathrm{I}-\mathrm{V}$ & 3 & 24 & - & $30-90$ & 47 \\
\hline $\begin{array}{c}\mathrm{CH}_{3} \mathrm{NH}_{3} \mathrm{PbBr}_{3} \\
\text { Film } \\
\end{array}$ & Fluorescence & - & 250 & $30-70$ & $7-98$ & 48 \\
\hline
\end{tabular}




\begin{tabular}{|c|c|c|c|c|c|c|}
\hline $\begin{array}{c}\mathrm{CH}_{3} \mathrm{NH}_{3} \mathrm{PbI}_{3} \\
\text { Stripes }\end{array}$ & $\mathrm{I}-\mathrm{V}$ & 4 & 0.1 & 0.5 & $10-95$ & $\begin{array}{c}\text { Present } \\
\text { work }\end{array}$ \\
\hline
\end{tabular}

Recently, it is reported that hybrid perovskites can act as oxygen $\left(\mathrm{O}_{2}\right)$ sensors by a trap healing mechanism, ${ }^{49}$ which contradicts with one previous study. ${ }^{46}$ To investigate the effect of oxygen, we exposed the perovskite stripes and single crystals to oxygen and found no significant change in the device resistance (Figure S8). Due to the dissimilar quality of perovskite films by various methods, there is a possibility of different electronic defects and charge transport characteristics, which might explain the contrasting results reported in different studies.

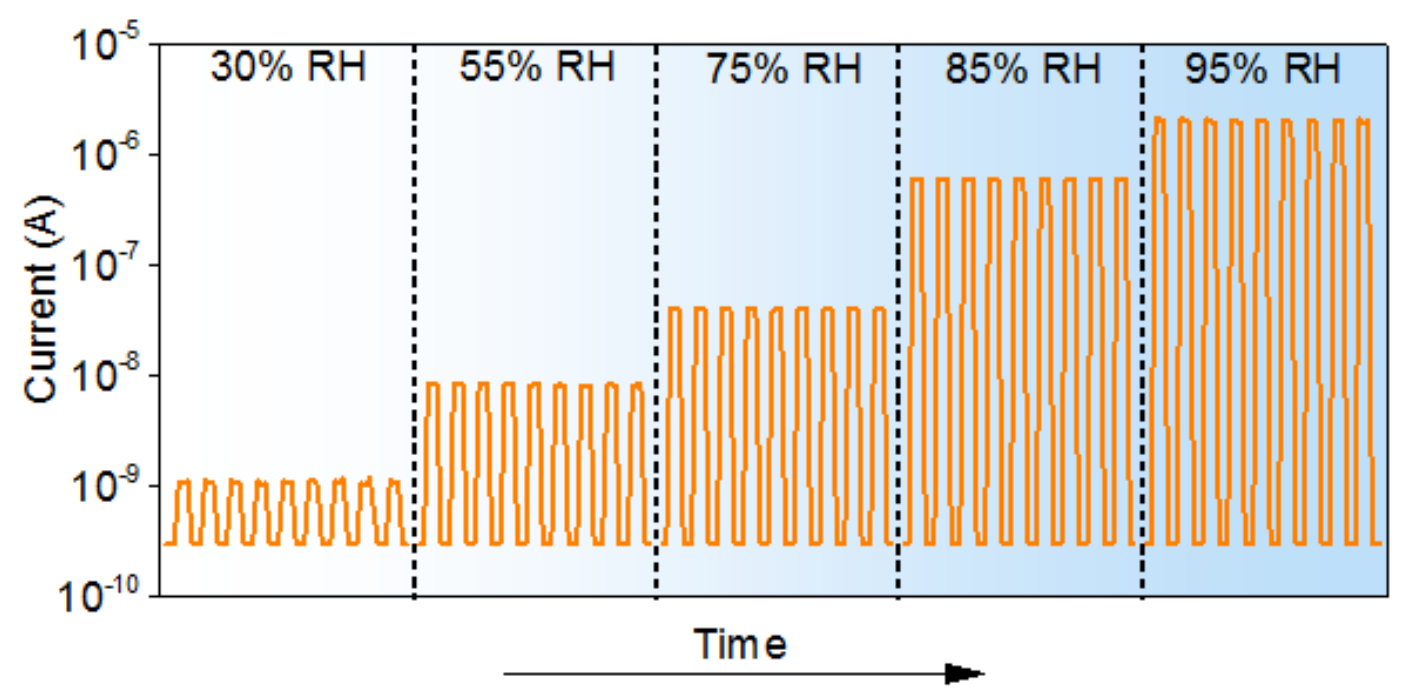

Figure 3. Sensor response to multiple cycles of humidity switching.

The mechanism for enhanced conductivity of perovskites with increasing humidity levels is quite complex in nature. There is an interplay between sample morphology and water-perovskite interaction in determining the conductivity. The enhanced conductivity of the perovskite sensor is related to surface mechanisms as supported by the short dehumidification time. As discussed earlier, grain boundaries play a vital role, which is also clear from the observation that single crystals show minimal enhancement in conductivity compared to stripes and films. ${ }^{50}$ Further, it is suggested that the water molecules act as strong n-type dopant, enhancing the conductivity by 
donating electrons to the perovskite. ${ }^{25,51}$ According to recent reports, water molecules on perovskite surface interact electrostatically and fill deep charge carrier traps as well. ${ }^{23,51,52}$ The majority carrier type in hybrid perovskites strongly depends on growth conditions. ${ }^{53}$ Furthermore, while $\mathrm{CH}_{3} \mathrm{NH}_{3} \mathrm{PbI}_{3}$ exhibits both p-type and n-type conductivity depending on intrinsic defects, $\mathrm{CH}_{3} \mathrm{NH}_{3} \mathrm{PbBr}_{3}$ only exhibits unipolar p-type conductivity. ${ }^{54-56}$ We hypothesize that the as-synthesized I-based perovskites in the present study are slightly $\mathrm{n}$-doped.$^{51}$ This is consistent with the observation that the conductivity of the perovskite monotonically increases with increasing humidity. For p-type samples, the conductivity is expected to decrease due to electron donation from water molecules and reduced hole density. ${ }^{57}$ This is similar to the case of ceramic oxide based humidity sensors where the enhanced conductivity is attributed to electron donation from water molecules to the oxide surfaces. As a general rule, the sensor conductivity increases for n-type oxides, while it decreases for p-type ones. ${ }^{58}$ To prove this hypothesis, we fabricated a device on $\mathrm{CH}_{3} \mathrm{NH}_{3} \mathrm{PbBr}_{3}$ single crystal. Its conductivity decreased with increasing humidity, indicating that $\mathrm{CH}_{3} \mathrm{NH}_{3} \mathrm{PbBr}_{3}$ single crystal is p-type, consistent with our hypothesis (Figure S9).

A plausible scenario of perovskite-moisture interactions is schematically represented in Figure 4. Moderate humidity levels or short exposure to high humidity leads to electron transfer from water molecules to perovskite lattice. However, exposure to high humidity levels for longer durations leads to degradation of the perovskite via different routes. In general, there are two main pathways pertaining to $\mathrm{CH}_{3} \mathrm{NH}_{3} \mathrm{PbI}_{3}$ degradation in the presence of humidity. The first pathway is governed by the catalytic action where water triggers the deprotonation of $\mathrm{MA}^{+}$, leading to the degradation of perovskites into $\mathrm{PbI}_{2}$ and molecular gases. ${ }^{23,59}$ In the second mechanism, $\mathrm{CH}_{3} \mathrm{NH}_{3} \mathrm{PbI}_{3} \cdot \mathrm{H}_{2} \mathrm{O}$ and $\left(\mathrm{CH}_{3} \mathrm{NH}_{3}\right)_{4} \mathrm{PbI}_{6} \cdot 2 \mathrm{H}_{2} \mathrm{O}$ are formed in the presence of moisture, 
eventually resulting in the degradation of perovskite. ${ }^{45}$ According to previous reports, hydration of perovskite $\left(\mathrm{CH}_{3} \mathrm{NH}_{3} \mathrm{PbI}_{3} \cdot \mathrm{H}_{2} \mathrm{O}\right.$ or $\left.\left(\mathrm{CH}_{3} \mathrm{NH}_{3}\right)_{4} \mathrm{PbI}_{6} \cdot 2 \mathrm{H}_{2} \mathrm{O}\right)$ is reversible when the humidity level is moderate or the sample is exposed afterwards to a dry gas such as $\mathrm{N}_{2}{ }^{50}$ In particular, $\mathrm{CH}_{3} \mathrm{NH}_{3} \mathrm{PbI}_{3} \cdot \mathrm{H}_{2} \mathrm{O}$ is known to be metastable and capable of losing the water molecule spontaneously, transforming back to $\mathrm{CH}_{3} \mathrm{NH}_{3} \mathrm{PbI}_{3}{ }^{60}$

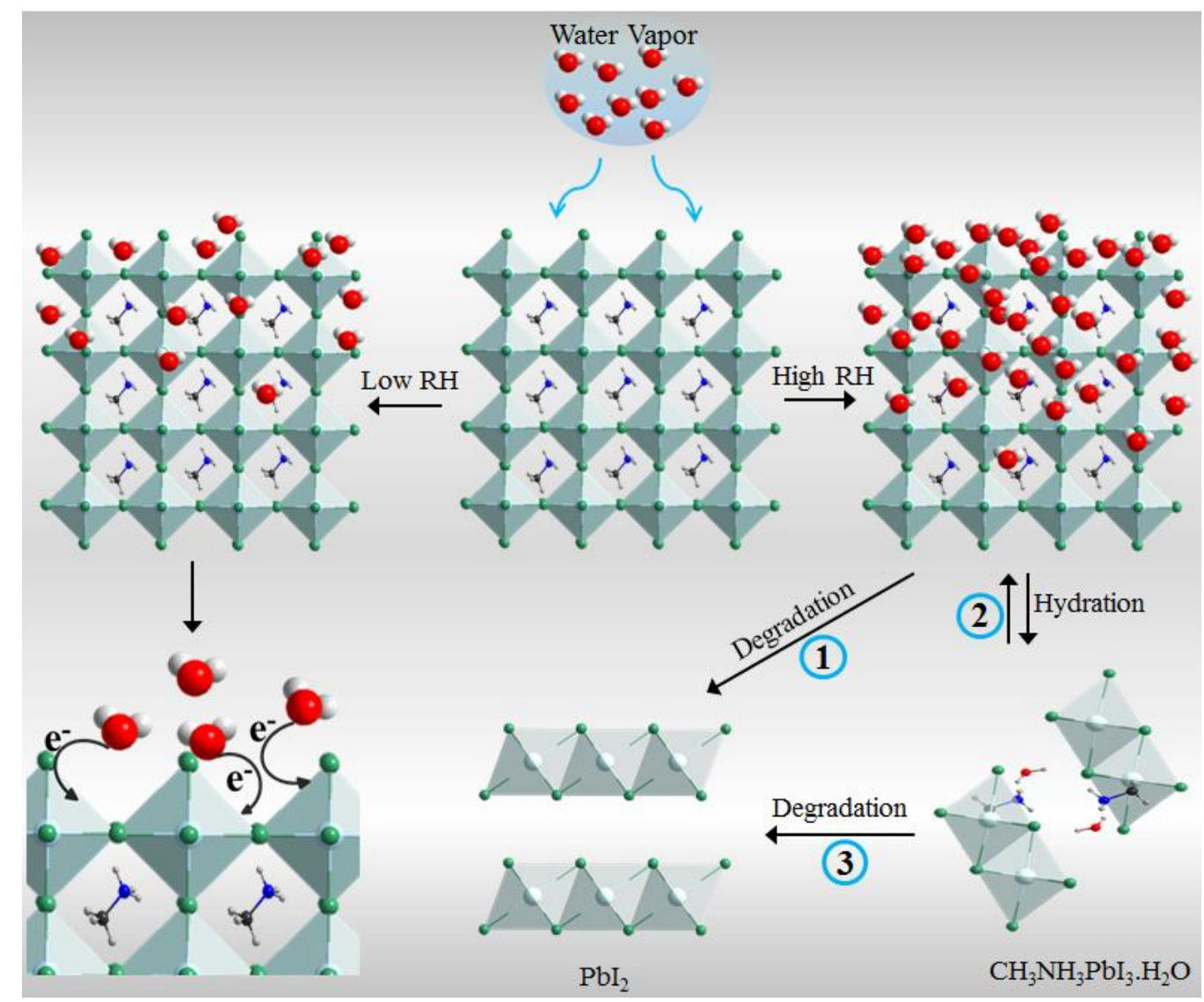

Figure 4. Illustration of the perovskite-moisture interaction, leading to electron transfer, hydration, and degradation.

Interestingly, different degradation pathways, rates, and products were identified in prior studies. ${ }^{61-67}$ Again this closely depends on the growth conditions, composition, and quality of the perovskite sample as well as measurement conditions. To gain an understanding of the effect of humidity, hydration/regeneration process and degradation pathways of two-step deposited perovskites, we exposed $\mathrm{CH}_{3} \mathrm{NH}_{3} \mathrm{PbI}_{3}$ samples to different humidity levels. There was no 
significant color change of $\mathrm{CH}_{3} \mathrm{NH}_{3} \mathrm{PbI}_{3}$ for 30-minute exposure to different humidity levels (Figure 5a). Interestingly, even after exposing $\mathrm{CH}_{3} \mathrm{NH}_{3} \mathrm{PbI}_{3}$ to $75 \% \mathrm{RH}$ for 6 hours, we did not observe any color change while partial and full discoloration occurred for samples at $85 \% \mathrm{RH}$ and 95\% RH, respectively (Figure $\mathbf{S} 10$ ). This is consistent with water sorption behavior where high water uptake was observed after $80 \%$ RH.

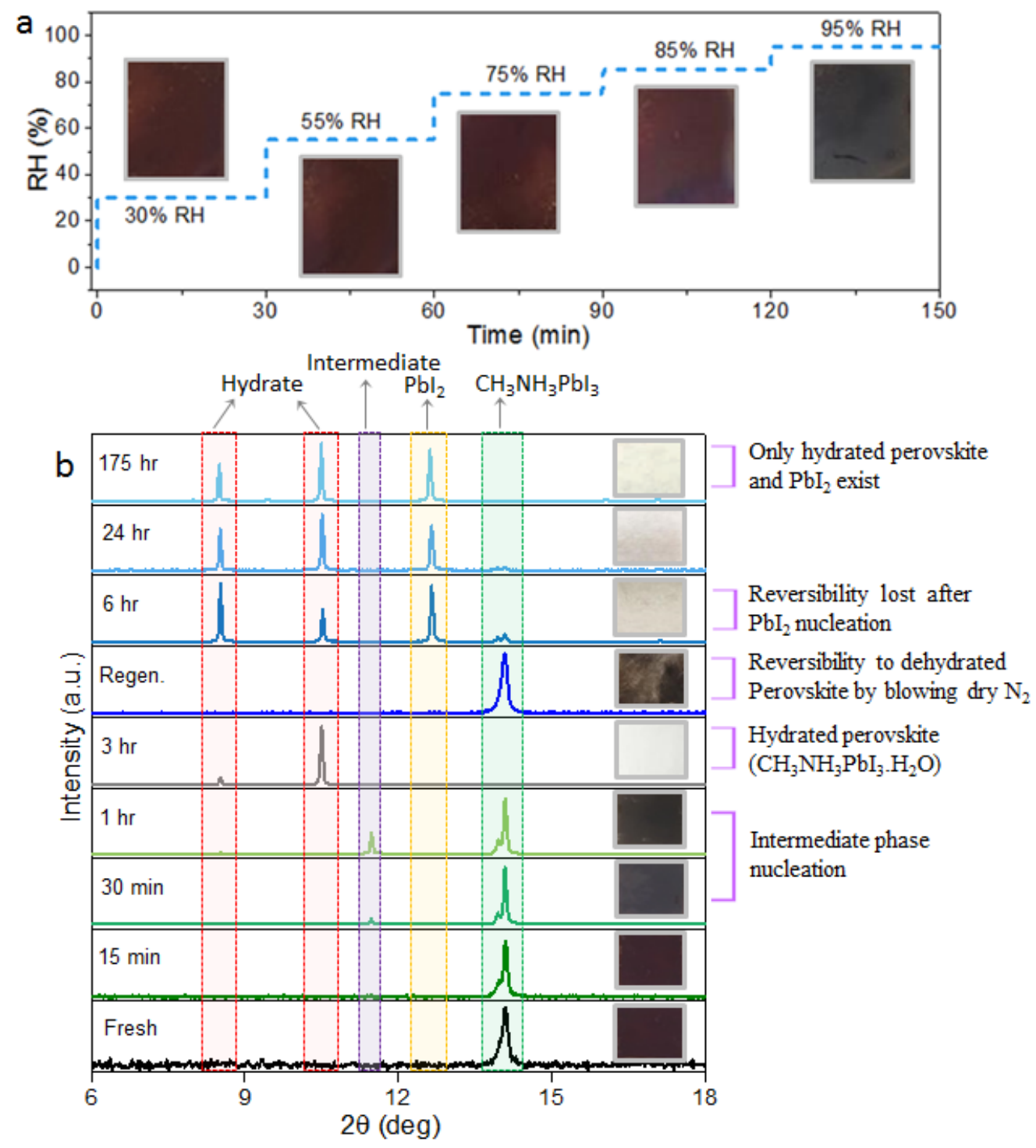

Figure 5. (a) Photographs of $\mathrm{CH}_{3} \mathrm{NH}_{3} \mathrm{PbI}_{3}$ at various $\mathrm{RH}$ levels after exposure for 30 minutes. (b) XRD patterns following the evolution of the fresh $\mathrm{CH}_{3} \mathrm{NH}_{3} \mathrm{PbI}_{3}$ film to the hydrated perovskite and then to the nucleation of $\mathrm{PbI}_{2}$ phase. Insets show the corresponding photographs of the sample. 
We monitored the chemical and structural changes occurring at high humidity by exposing $\mathrm{CH}_{3} \mathrm{NH}_{3} \mathrm{PbI}_{3}$ to $95 \% \mathrm{RH}$ for a period of 175 hours (Figure 5b). Photos and XRD spectra were collected during this period to identify the degradation pathway. All the major XRD peaks belong to perovskite, but hydrated perovskite and $\mathrm{PbI}_{2}$ appear at the low angles after moisture exposure. $\mathrm{A} \mathrm{CH}_{3} \mathrm{NH}_{2}$-incorporated intermediate phase was detected around $11.5^{\circ}$ in the XRD after 30 min exposure whose intensity increased after 1-hour humidity exposure, ${ }^{68}$ and it disappeared after longer moisture exposure. After 3 hours of exposure, complete hydration of $\mathrm{CH}_{3} \mathrm{NH}_{3} \mathrm{PbI}_{3}$ occurred resulting in a colorless film. The XRD pattern of the colorless film exhibits diffraction peaks around $8.5^{\circ}$ and $10.5^{\circ}$, which can be ascribed to formation of monohydrate perovskite, $\mathrm{CH}_{3} \mathrm{NH}_{3} \mathrm{PbI}_{3} \cdot \mathrm{H}_{2} \mathrm{O} .{ }^{50}$ On flushing $\mathrm{CH}_{3} \mathrm{NH}_{3} \mathrm{PbI}_{3} \cdot \mathrm{H}_{2} \mathrm{O}$ with dry $\mathrm{N}_{2}$ for 5 minutes, the colorless film reverted back to black color as a result of $\mathrm{CH}_{3} \mathrm{NH}_{3} \mathrm{PbI}_{3}$ regeneration, which is accompanied by the reappearance of $\mathrm{CH}_{3} \mathrm{NH}_{3} \mathrm{PbI}_{3}$ XRD peak. The color of the regenerated perovskite was not as dark as the fresh sample. Similar effects of regeneration were observed when hydrated films were flushed with dry air or dry oxygen.

To gain more insight about the hydration and regeneration process, Fourier transform infrared (FTIR) spectra were recorded for fresh, hydrated and regenerated $\mathrm{CH}_{3} \mathrm{NH}_{3} \mathrm{PbI}_{3}$ films (Figure 6a). The presence of the broad peak around $3500 \mathrm{~cm}^{-1}$ in the case of fresh film indicates that water molecules are readily adsorbed by $\mathrm{CH}_{3} \mathrm{NH}_{3} \mathrm{PbI}_{3}$ film upon exposure to ambient environment. The FTIR spectra of hydrated $\left(\mathrm{CH}_{3} \mathrm{NH}_{3} \mathrm{PbI}_{3} \cdot \mathrm{H}_{2} \mathrm{O}\right)$ film exhibits two well-defined peaks (Figure 6b) in the region $3400-3500 \mathrm{~cm}^{-1}$ in contrast to the broad peak as observed in the case of fresh film. These two peaks are associated with $\mathrm{O}-\mathrm{H}$ vibrations in isolated water molecules with relatively strong hydrogen bonding. ${ }^{69,70}$ Additional changes in FTIR spectra of the hydrated sample can be observed in the regions around $1600 \mathrm{~cm}^{-1}$ and $3000 \mathrm{~cm}^{-1}$ due to water 
induced modifications. The hydrated film reverted back completely on flushing with dry $\mathrm{N}_{2}$, and the FTIR spectrum of the regenerated film matches that of the fresh film. Both XRD and FTIR analysis confirms that dry $\mathrm{N}_{2}$ is capable of removing water molecules from the perovskite film thus enhancing the stability.
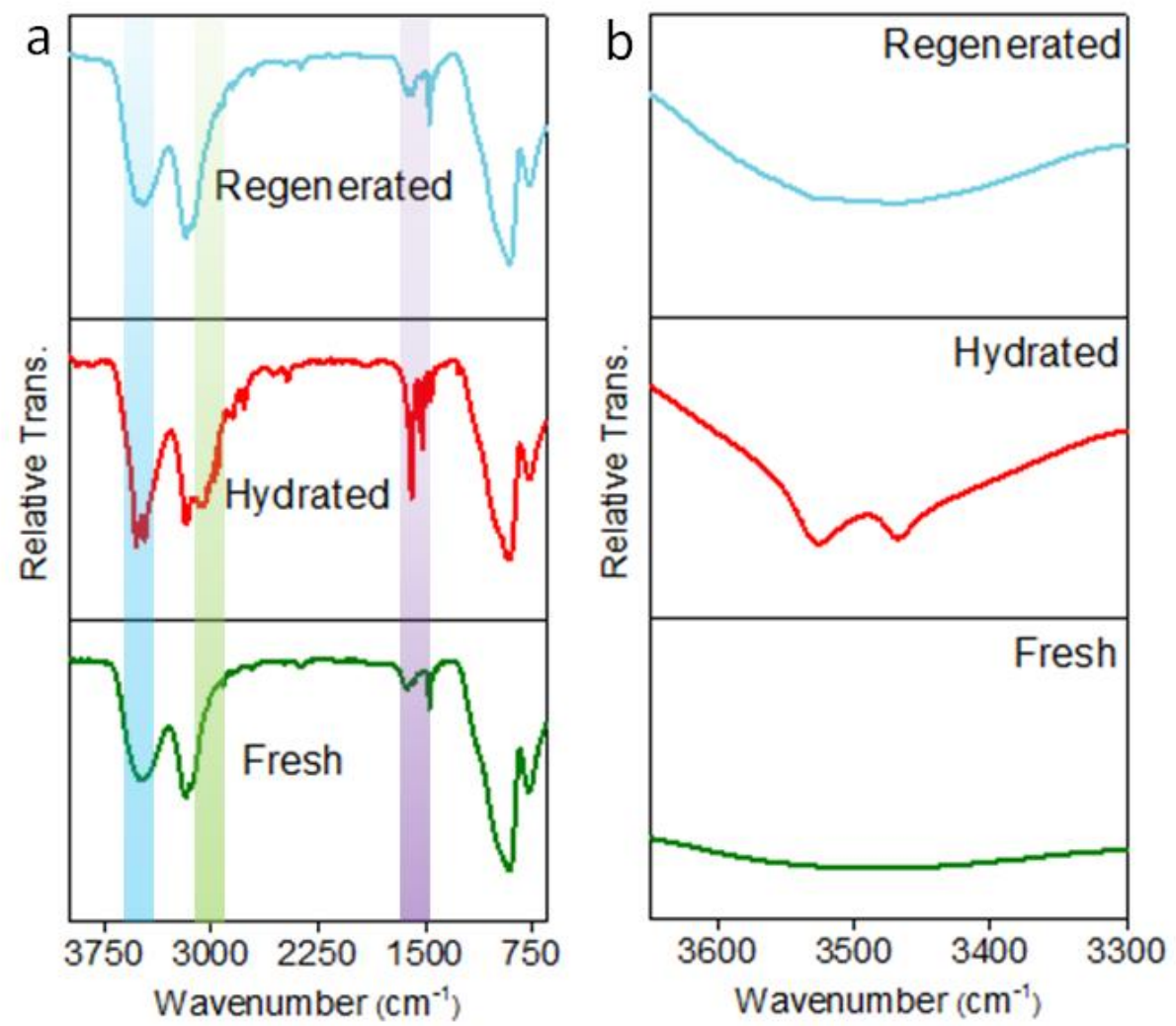

Figure 6. (a) FTIR spectra of fresh, hydrated, and regenerated perovskite film. (b) Enlarged view of FTIR spectra in the region $3600-3300 \mathrm{~cm}^{-1}$ showing the presence of isolated water molecules.

The reversible effect was lost when the $\mathrm{CH}_{3} \mathrm{NH}_{3} \mathrm{PbI}_{3}$ was treated for a very long period of time (6 hours) due to the nucleation of $\mathrm{PbI}_{2}$ phase. After 24 hour exposure, the peak intensity of the hydrated perovskite increased. Interestingly, even after 175 hours of exposure to $95 \%$ RH, hydrated perovskite phase and $\mathrm{PbI}_{2}$ coexist as evident from the XRD spectra, and the sample appears colorless. To completely degrade the sample, we exposed it to $100 \% \mathrm{RH}$ which lead to the appearance of yellow color due to the removal of the hydrated perovskite phase (Figure 
S11). At $100 \% \mathrm{RH}$, condensation of water takes place on the surface, which induces the formation of $\mathrm{PbI}_{2}$. It is noteworthy that we did not observe the formation of $\left(\mathrm{CH}_{3} \mathrm{NH}_{3}\right)_{4} \mathrm{PbI}_{6} \cdot 2 \mathrm{H}_{2} \mathrm{O}$ even after the sample was exposed to high humidity for more than 7 days. This indicates that the degradation pathway of perovskites is sensitive to sample preparation and structural details.

\section{CONCLUSIONS}

In conclusion, we fabricated long-range perovskite micro-stripes employing the standard photolithography technique and studied their response to humidity using a simple sensor architecture. Water sorption measurements revealed there is an orderly correlation between the sensor resistance and water uptake. Light-dependent measurements in the presence of humidity revealed that $\mathrm{CH}_{3} \mathrm{NH}_{3} \mathrm{PbI}_{3}$ based optoelectronic devices should be operated below 33\% $\mathrm{RH}$ for optimal performance. An upper limit of $85 \% \mathrm{RH}$ was observed beyond which $\mathrm{CH}_{3} \mathrm{NH}_{3} \mathrm{PbI}_{3}$ was not photoactive anymore. Furthermore, we monitored the chemical changes occurring at high humidity levels and elucidate the effect of hydration and reversible behavior of two-step deposited $\mathrm{CH}_{3} \mathrm{NH}_{3} \mathrm{PbI}_{3}$. Our results shed light on the moisture-perovskite interaction, crucial for developing robust devices in the future.

\section{ASSOCIATED CONTENT}

\section{Supporting Information}

The Supporting Information is available free of charge on the ACS Publications website at DOI: Measurement set up for the humidity tests, flexibility test data, performance of films and single crystals under humidity.

\section{AUTHOR INFORMATION}

Corresponding Author: tom.wu@unsw.edu.au

Notes

The authors declare no competing financial interests. 


\section{ACKNOWLEDGEMENT}

Research reported in this publication was supported by the King Abdullah University of Science and Technology (KAUST).

\section{REFERENCES}

(1) Park, N.-G.; Grätzel, M.; Miyasaka, T.; Zhu, K.; Emery, K. Towards stable and Commercially Available Perovskite Solar Cells. Nat. Energy 2016, 1, 16152.

(2) Fu, A.; Yang, P. Organic-Inorganic Perovskites: Lower Threshold for Nanowire Lasers. Nat. Mater. 2015, 14, 557-558.

(3) Stranks, S. D.; Snaith, H. J. Metal-Halide Perovskites for Photovoltaic and Light-Emitting Devices. Nat. Nanotechnol. 2015, 10, 391-402.

(4) Saidaminov, M. I.; Haque, M. A.; Savoie, M.; Abdelhady, A. L.; Cho, N.; Dursun, I.; Buttner, U.; Alarousu, E.; Wu, T.; Bakr, O. M. Perovskite Photodetectors Operating in Both Narrowband and Broadband Regimes. Adv. Mater. 2016, 28, 8144-8149.

(5) Sheikh, A. D.; Munir, R.; Haque, M. A.; Bera, A.; Hu, W.; Shaikh, P.; Amassian, A.; Wu, T. Effects of High Temperature and Thermal Cycling on the Performance of Perovskite Solar Cells: Acceleration of Charge Recombination and Deterioration of Charge Extraction. ACS Appl. Mater. Interfaces 2017, 9, 35018-35029.

(6) Yu, Y.; Zhang, Y.; Zhang, Z.; Zhang, H.; Song, X.; Cao, M.; Che, Y.; Dai, H.; Yang, J.; Wang, J.; Zhang, H.; Yao, J. Broadband Phototransistor Based on $\mathrm{CH}_{3} \mathrm{NH}_{3} \mathrm{PbI}_{3}$ Perovskite and PbSe Quantum Dot Heterojunction. J. Phys. Chem. Lett. 2017, 8, 445-451.

(7) Rakita, Y.; Bar-Elli, O.; Meirzadeh, E.; Kaslasi, H.; Peleg, Y.; Hodes, G.; Lubomirsky, I.; Oron, D.; Ehre, D.; Cahen, D. Tetragonal $\mathrm{CH}_{3} \mathrm{NH}_{3} \mathrm{PbI}_{3}$ is Ferroelectric. Proc. Natl. Acad. Sci. 2017, 114, E5504.

(8) Zhou, Y.; You, L.; Wang, S.; Ku, Z.; Fan, H.; Schmidt, D.; Rusydi, A.; Chang, L.; Wang, L.; Ren, P.; Chen, L.; Yuan, G.; Chen, L.; Wang, J. Giant Photostriction in Organic-Inorganic Lead Halide Perovskites. Nat. Commun. 2016, 7, 11193.

(9) Guan, X.; Hu, W.; Haque, M. A.; Wei, N.; Liu, Z.; Chen, A.; Wu, T. Light-Responsive IonRedistribution-Induced Resistive Switching in Hybrid Perovskite Schottky Junctions. Adv. Funct. Mater. 2018, 28, 1704665.

(10) Ha, S.-T.; Shen, C.; Zhang, J.; Xiong, Q. Laser Cooling of Organic-Inorganic Lead Halide Perovskites. Nat. Photonics 2015, 10, 115-121.

(11) Brittman, S.; Oener, S. Z.; Guo, K.; Ābolinšs, H.; Koenderink, A. F.; Garnett, E. C. Controlling Crystallization to Imprint Nanophotonic Structures into Halide Perovskites Using Soft Lithography. J. Mater. Chem. C 2017, 5, 8301-8307.

(12) Feng, J.; Yan, X.; Liu, Y.; Gao, H.; Wu, Y.; Su, B.; Jiang, L. Crystallographically Aligned Perovskite Structures for High-Performance Polarization-Sensitive Photodetectors. Adv. Mater. 2017, 29, 1605993.

(13) Lee, W.; Lee, J.; Yun, H.; Kim, J.; Park, J.; Choi, C.; Kim, D. C.; Seo, H.; Lee, H.; Yu, J. W.; Lee, W. B.; Kim, D. H. High-Resolution Spin-on-Patterning of Perovskite Thin Films for a Multiplexed Image Sensor Array. Adv. Mater. 2017, 29, 1702902.

(14) Wu, J.; Chen, J.; Zhang, Y.; Xu, Z.; Zhao, L.; Liu, T.; Luo, D.; Yang, W.; Chen, K.; Hu, Q.; Ye, F.; Wu, P.; Zhu, R.; Gong, Q. Pinhole-Free Hybrid Perovskite Film with Arbitrarily-Shaped Micro-Patterns for Functional Optoelectronic Devices. Nano Lett. 2017, 17, 3563-3569. 
(15) Lee, L.; Baek, J.; Park, K. S.; Lee, Y. E.; Shrestha, N. K.; Sung, M. M. Wafer-Scale SingleCrystal Perovskite Patterned Thin Films Based on Geometrically-Confined Lateral Crystal Growth. Nat. Commun. 2017, 8, 15882.

(16) Wang, Q.; Chen, B.; Liu, Y.; Deng, Y.; Bai, Y.; Dong, Q.; Huang, J. Scaling Behavior of Moisture-Induced Grain Degradation in Polycrystalline Hybrid Perovskite Thin Films. Energy Environ. Sci. 2017, 10, 516-522.

(17) Eperon, G. E.; Habisreutinger, S. N.; Leijtens, T.; Bruijnaers, B. J.; van Franeker, J. J.; deQuilettes, D. W.; Pathak, S.; Sutton, R. J.; Grancini, G.; Ginger, D. S.; Janssen, R. A.; Petrozza, A.; Snaith, H. J. The Importance of Moisture in Hybrid Lead Halide Perovskite Thin Film Fabrication. ACS Nano 2015, 9, 9380-9393.

(18) Kadro, J. M.; Nonomura, K.; Gachet, D.; Gratzel, M.; Hagfeldt, A. Facile Route to Freestanding $\mathrm{CH}_{3} \mathrm{NH}_{3} \mathrm{PbI}_{3}$ Crystals Using Inverse Solubility. Sci. Rep. 2015, 5, 11654.

(19) Shi, D.; Adinolfi, V.; Comin, R.; Yuan, M.; Alarousu, E.; Buin, A.; Chen, Y.; Hoogland, S.; Rothenberger, A.; Katsiev, K.; Losovyj, Y.; Zhang, X.; Dowben, P. A.; Mohammed, O. F.; Sargent, E. H.; Bakr, O. M. Solar cells. Low Trap-State Density and Long Carrier Diffusion in Organolead Trihalide Perovskite Single Crystals. Science 2015, 347, 519-522.

(20) Xue, Q.; Xia, R.; Brabec, C. J.; Yip, H.-L. Recent Advances in Semi-Transparent Polymer and Perovskite Solar Cells for Power Generating Window Applications. Energy Environ. Sci. 2018, 11, 1688-1709.

(21) Yoon, B.; Liu, S. F.; Swager, T. M. Surface-Anchored Poly(4-vinylpyridine)-Single-Walled Carbon Nanotube-Metal Composites for Gas Detection. Chem. Mater. 2016, 28, 5916-5924.

(22) Shevate, R.; Haque, M. A.; Akhtar, F. H.; Villalobos, L. F.; Wu, T.; Peinemann, K. V. Embedding 1D Conducting Channels into 3D Isoporous Polymer Films for High-Performance Humidity Sensing. Angew. Chem. Int. Ed. Engl. 2018, 57, 11218-11222.

(23) Huang, J.; Tan, S.; Lund, P. D.; Zhou, H. Impact of $\mathrm{H}_{2} \mathrm{O}$ on Organic-Inorganic Hybrid Perovskite Solar Cells. Energy Environ. Sci. 2017, 10, 2284-2311.

(24) Schlipf, J.; Biessmann, L.; Oesinghaus, L.; Berger, E.; Metwalli, E.; Lercher, J. A.; Porcar, L.; Muller-Buschbaum, P. In Situ Monitoring the Uptake of Moisture into Hybrid Perovskite Thin Films. J. Phys. Chem. Lett. 2018, 9, 2015-2021.

(25) Song, Z.; Shrestha, N.; Watthage, S. C.; Liyanage, G. K.; Almutawah, Z. S.; Ahangharnejhad, R. H.; Phillips, A. B.; Ellingson, R. J.; Heben, M. J. Impact of Moisture on Photoexcited Charge Carrier Dynamics in Methylammonium Lead Halide Perovskites. J. Phys. Chem. Lett. 2018, 9, 6312-6320.

(26) Wang, Z.; Shi, L.; Wu, F.; Yuan, S.; Zhao, Y.; Zhang, M. The Sol-Gel Template Synthesis of Porous $\mathrm{TiO}_{2}$ for a High Performance Humidity Sensor. Nanotechnology 2011, 22, 275502.

(27) Li, Z.; Zhang, H.; Zheng, W.; Wang, W.; Huang, H.; Wang, C.; MacDiarmid, A. G.; Wei, Y. Highly Sensitive and Stable Humidity Nanosensors Based on $\mathrm{LiCl}$ Doped $\mathrm{TiO}_{2}$ Electrospun Nanofibers. J. Am. Chem. Soc. 2008, 130, 5036-5037.

(28) Hu, X.; Gong, J.; Zhang, L.; Yu, J. C. Continuous Size Tuning of Monodisperse ZnO Colloidal Nanocrystal Clusters by a Microwave-Polyol Process and Their Application for Humidity Sensing. Adv. Mater. 2008, 20, 4845-4850.

(29) Sun, A.; Huang, L.; Li, Y. Study on Humidity Sensing Property Based on $\mathrm{TiO}_{2}$ Porous Film and Polystyrene Sulfonic Sodium. Sens. Actuator B-Chem. 2009, 139, 543-547.

(30) Shi, J.; Hsiao, V. K. S.; Walker, T. R.; Huang, T. J. Humidity Sensing Based on Nanoporous Polymeric Photonic Crystals. Sens. Actuator B-Chem. 2008, 129, 391-396. 
(31) Demir, R.; Okur, S.; Şeker, M. Electrical Characterization of CdS Nanoparticles for Humidity Sensing Applications. Ind. Eng. Chem. Res. 2012, 51, 3309-3313.

(32) Zainelabdin, A.; Amin, G.; Zaman, S.; Nur, O.; Lu, J.; Hultman, L.; Willander, M. $\mathrm{CuO} / \mathrm{ZnO}$ Nanocorals Synthesis via Hydrothermal Technique: Growth Mechanism and Their Application as Humidity Sensor. J. Mater. Chem. 2012, 22, 11583-11590.

(33) Wang, P.; Zhang, L.; Xia, Y.; Tong, L.; Xu, X.; Ying, Y. Polymer Nanofibers Embedded with Aligned Gold Nanorods: A New Platform for Plasmonic Studies and Optical Sensing. Nano Lett. 2012, 12, 3145-3150.

(34) Kim, E.; Kim, S. Y.; Jo, G.; Kim, S.; Park, M. J. Colorimetric and Resistive Polymer Electrolyte Thin Films for Real-time Humidity Sensors. ACS Appl. Mater. Interfaces 2012, 4, 5179-5187.

(35) Cheng, B.; Tian, B.; Xie, C.; Xiao, Y.; Lei, S. Highly Sensitive Humidity Sensor Based on Amorphous $\mathrm{Al}_{2} \mathrm{O}_{3}$ Nanotubes. J. Mater. Chem. 2011, 21, 1907-1912.

(36) Lin, Q.; Li, Y.; Yang, M. Polyaniline Nanofiber Humidity Sensor Prepared by Electrospinning. Sens. Actuator B-Chem. 2012, 161, 967-972.

(37) Rubinger, C. P. L.; Martins, C. R.; De Paoli, M. A.; Rubinger, R. M. Sulfonated Polystyrene Polymer Humidity Sensor: Synthesis and Characterization. Sens. Actuator B-Chem. 2007, 123, 42-49.

(38) Zhang, H.; Li, Z.; Wang, W.; Wang, C.; Liu, L. $\mathrm{Na}^{+}$-Doped Zinc Oxide Nanofiber Membrane for High Speed Humidity Sensor. J. Am. Ceram. Soc. 2010, 93, 142-146.

(39) Lee, C.-W.; Joo, S.-W.; Gong, M.-S. Polymeric Humidity Sensor Using Polyelectrolytes Derived from Alkoxysilane Cross-Linker. Sens. Actuator B-Chem. 2005, 105, 150-158.

(40) Ueda, M.; Nakamura, K.; Tanaka, K.; Kita, H.; Okamoto, K.-i. Water-Resistant Humidity Sensors Based on Sulfonated Polyimides. Sens. Actuator B-Chem. 2007, 127, 463-470.

(41) Kuang, Q.; Lao, C.; Wang, Z. L.; Xie, Z.; Zheng, L. High-Sensitivity Humidity Sensor Based on a Single $\mathrm{SnO}_{2}$ Nanowire. J. Am. Chem. Soc. 2007, 129, 6070-6071.

(42) Li, D.; Zhang, J.; Shen, L.; Dong, W.; Feng, C.; Liu, C.; Ruan, S. Humidity Sensing Properties of $\mathrm{SrTiO}_{3}$ Nanospheres with High Sensitivity and Rapid Response. RSC Adv. 2015, 5 , 22879-22883.

(43) Parveen, A.; Koppalkar, A. R.; Roy, A. S. Surface Modified $\mathrm{CaTiO}_{3}$ Loaded in Polyaniline by Sodium Dodecyl Benzene Sulphonic Acid for Humidity Sensor. IEEE Sens. J. 2012, 12, 2817-2823.

(44) Mosca, R.; Ferro, P.; Besagni, T.; Calestani, D.; Chiarella, F.; Licci, F. Effect of Humidity on the A.C. Impedance of $\mathrm{CH}_{3} \mathrm{NH}_{3} \mathrm{SnCl}_{3}$ Hybrid Films. Appl. Phys. A 2011, 104, 1181-1187.

(45) Deretzis, I.; Smecca, E.; Mannino, G.; La Magna, A.; Miyasaka, T.; Alberti, A. Stability and Degradation in Hybrid Perovskites: Is the Glass Half-Empty or Half-Full? J. Phys. Chem. Lett. 2018, 9, 3000-3007.

(46) Hu, L.; Shao, G.; Jiang, T.; Li, D.; Lv, X.; Wang, H.; Liu, X.; Song, H.; Tang, J.; Liu, H. Investigation of the Interaction between Perovskite Films with Moisture via in Situ Electrical Resistance Measurement. ACS Appl. Mater. Interfaces 2015, 7, 25113-25120.

(47) Ren, K.; Huang, L.; Yue, S.; Lu, S.; Liu, K.; Azam, M.; Wang, Z.; Wei, Z.; Qu, S.; Wang, Z. Turning a Disadvantage into an Advantage: Synthesizing High-Quality Organometallic Halide Perovskite Nanosheet Arrays for Humidity Sensors. J. Mater. Chem. C 2017, 5, 2504-2508.

(48) Xu, W.; Li, F.; Cai, Z.; Wang, Y.; Luo, F.; Chen, X. An Ultrasensitive and Reversible Fluorescence Sensor of Humidity Using Perovskite $\mathrm{CH}_{3} \mathrm{NH}_{3} \mathrm{PbBr}_{3}$. J. Mater. Chem. C 2016, 4 , 9651-9655. 
(49) Stoeckel, M. A.; Gobbi, M.; Bonacchi, S.; Liscio, F.; Ferlauto, L.; Orgiu, E.; Samori, P. Reversible, Fast, and Wide-Range Oxygen Sensor Based on Nanostructured Organometal Halide Perovskite. Adv. Mater. 2017, 29, 1702469.

(50) Leguy, A. M. A.; Hu, Y.; Campoy-Quiles, M.; Alonso, M. I.; Weber, O. J.; Azarhoosh, P.; van Schilfgaarde, M.; Weller, M. T.; Bein, T.; Nelson, J.; Docampo, P.; Barnes, P. R. F. Reversible Hydration of $\mathrm{CH}_{3} \mathrm{NH}_{3} \mathrm{PbI}_{3}$ in Films, Single Crystals, and Solar Cells. Chem. Mater. 2015, 27, 3397-3407.

(51) Li, Y.; Xu, X.; Wang, C.; Wang, C.; Xie, F.; Yang, J.; Gao, Y. Degradation by Exposure of Coevaporated $\mathrm{CH}_{3} \mathrm{NH}_{3} \mathrm{PbI}_{3}$ Thin Films. J. Phys. Chem. C 2015, 119, 23996-24002.

(52) Long, R.; Fang, W.; Prezhdo, O. V. Moderate Humidity Delays Electron-Hole Recombination in Hybrid Organic-Inorganic Perovskites: Time-Domain Ab Initio Simulations Rationalize Experiments. J. Phys. Chem. Lett. 2016, 7, 3215-3222.

(53) Wu, T.; Mukherjee, R.; Ovchinnikova, O. S.; Collins, L.; Ahmadi, M.; Lu, W.; Kang, N. G.; Mays, J. W.; Jesse, S.; Mandrus, D.; Hu, B. Metal/Ion Interactions Induced p-i-n Junction in Methylammonium Lead Triiodide Perovskite Single Crystals. J. Am. Chem. Soc. 2017, 139, $17285-17288$.

(54) Yin, W.-J.; Shi, T.; Yan, Y. Unusual Defect Physics in $\mathrm{CH}_{3} \mathrm{NH}_{3} \mathrm{PbI}_{3}$ Perovskite Solar Cell Absorber. Appl. Phys. Lett. 2014, 104, 063903.

(55) Wang, R.; Zhang, X.; He, J.; Ma, C.; Xu, L.; Sheng, P.; Huang, F. Bi ${ }^{3+}$-Doped $\mathrm{CH}_{3} \mathrm{NH}_{3} \mathrm{PbI}_{3}$ : Red-Shifting Absorption Edge and Longer Charge Carrier Lifetime. J. Alloys Compd. 2017, 695, 555-560.

(56) Shi, T.; Yin, W.-J.; Hong, F.; Zhu, K.; Yan, Y. Unipolar Self-Doping Behavior in Perovskite $\mathrm{CH}_{3} \mathrm{NH}_{3} \mathrm{PbBr}_{3}$. Appl. Phys. Lett. 2015, 106, 103902.

(57) Han, J.-W.; Kim, B.; Li, J.; Meyyappan, M. Carbon Nanotube Based Humidity Sensor on Cellulose Paper. J. Phys. Chem. C 2012, 116, 22094-22097.

(58) Chen, Z.; Lu, C. Humidity Sensors: A Review of Materials and Mechanisms. Sensor Lett. 2005, 3, 274-295.

(59) Manser, J. S.; Saidaminov, M. I.; Christians, J. A.; Bakr, O. M.; Kamat, P. V. Making and Breaking of Lead Halide Perovskites. Acc. Chem. Res. 2016, 49, 330-338.

(60) Hao, F.; Stoumpos, C. C.; Liu, Z.; Chang, R. P.; Kanatzidis, M. G. Controllable Perovskite Crystallization at a Gas-Solid Interface for Hole Conductor-Free Solar Cells with Steady Power Conversion Efficiency Over 10\%. J. Am. Chem. Soc. 2014, 136, 16411-16419.

(61) Salado, M.; Contreras-Bernal, L.; Caliò, L.; Todinova, A.; López-Santos, C.; Ahmad, S.; Borras, A.; Idígoras, J.; Anta, J. A. Impact of Moisture on Efficiency-Determining Electronic Processes in Perovskite Solar Cells. J. Mater. Chem. A 2017, 5, 10917-10927.

(62) Song, Z.; Abate, A.; Watthage, S. C.; Liyanage, G. K.; Phillips, A. B.; Steiner, U.; Graetzel, M.; Heben, M. J. Perovskite Solar Cell Stability in Humid Air: Partially Reversible Phase Transitions in the $\mathrm{PbI}_{2}-\mathrm{CH}_{3} \mathrm{NH}_{3} \mathrm{I}-\mathrm{H}_{2} \mathrm{O}$ System. Adv. Energy Mater. 2016, 6, 1600846.

(63) Zhao, J.; Cai, B.; Luo, Z.; Dong, Y.; Zhang, Y.; Xu, H.; Hong, B.; Yang, Y.; Li, L.; Zhang, W.; Gao, C. Investigation of the Hydrolysis of Perovskite Organometallic Halide $\mathrm{CH}_{3} \mathrm{NH}_{3} \mathrm{PbI}_{3}$ in Humidity Environment. Sci. Rep. 2016, 6, 21976.

(64) Yang, J.; Siempelkamp, B. D.; Liu, D.; Kelly, T. L. Investigation of $\mathrm{CH}_{3} \mathrm{NH}_{3} \mathrm{PbI}_{3}$ Degradation Rates and Mechanisms in Controlled Humidity Environments Using in Situ Techniques. ACS Nano 2015, 9, 1955-1963. 
(65) Li, D.; Bretschneider, S. A.; Bergmann, V. W.; Hermes, I. M.; Mars, J.; Klasen, A.; Lu, H.; Tremel, W.; Mezger, M.; Butt, H.-J.; Weber, S. A. L.; Berger, R. Humidity-Induced Grain Boundaries in $\mathrm{MAPbI}_{3}$ Perovskite Films. J. Phys. Chem. C 2016, 120, 6363-6368.

(66) Lv, Q.; He, W.; Lian, Z.; Ding, J.; Li, Q.; Yan, Q. Anisotropic Moisture Erosion of $\mathrm{CH}_{3} \mathrm{NH}_{3} \mathrm{PbI}_{3}$ Single Crystals. CrystEngComm 2017, 19, 901-904.

(67) Christians, J. A.; Miranda Herrera, P. A.; Kamat, P. V. Transformation of the Excited State and Photovoltaic Efficiency of $\mathrm{CH}_{3} \mathrm{NH}_{3} \mathrm{PbI}_{3}$ Perovskite upon Controlled Exposure to Humidified Air. J. Am. Chem. Soc. 2015, 137, 1530-1538.

(68) Jung, M.-C.; Kobori, S.; Matsuyama, A.; Maeng, I.; Lee, Y. M.; Kojima, H.; Benten, H.; Nakamura, M. Formation of $\mathrm{CH}_{3} \mathrm{NH}_{2}$-Incorporated Intermediate State in $\mathrm{CH}_{3} \mathrm{NH}_{3} \mathrm{PbI}_{3}$ Hybrid Perovskite Thin Film Formed by Sequential Vacuum Evaporation. Appl. Phys. Express 2019, 12, 015501.

(69) Müller, C.; Glaser, T.; Plogmeyer, M.; Sendner, M.; Döring, S.; Bakulin, A. A.; Brzuska, C.; Scheer, R.; Pshenichnikov, M. S.; Kowalsky, W.; Pucci, A.; Lovrinčić, R. Water Infiltration in Methylammonium Lead Iodide Perovskite: Fast and Inconspicuous. Chem. Mater. 2015, 27, 7835-7841.

(70) Idigoras, J.; Todinova, A.; Sanchez-Valencia, J. R.; Barranco, A.; Borras, A.; Anta, J. A. The Interaction Between Hybrid Organic-Inorganic Halide Perovskite and Selective Contacts in Perovskite Solar Cells: an Infrared Spectroscopy Study. Phys. Chem. Chem. Phys. 2016, 18, 13583-13590. 
TOC GRAPHICS

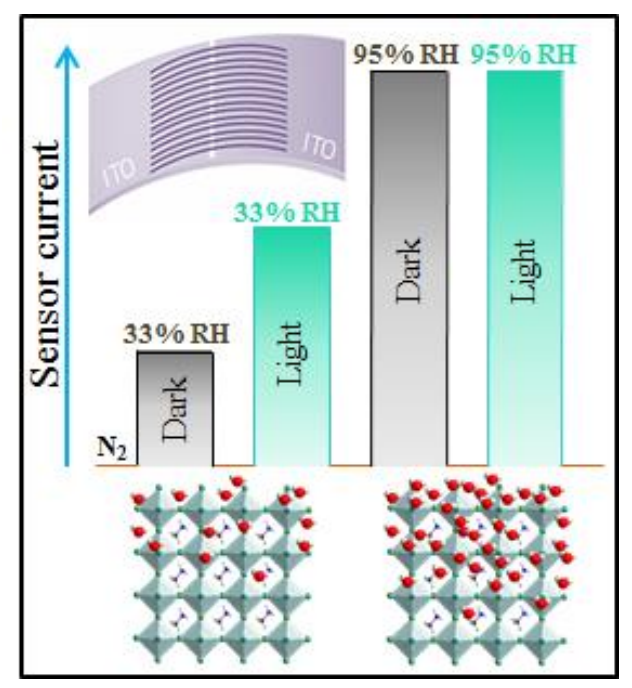

